\title{
Collusion in International Organizations: How States Benefit from the Authority of Secretariats
}

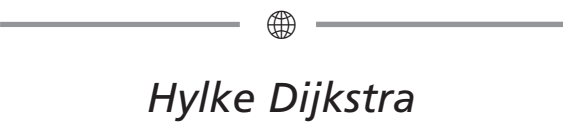

\begin{abstract}
In the theoretical literature on the authority of international secretariats, academics often dichotomize between states and secretariats. Even when they account for the fact that states are often divided, they normally adopt a twostep approach: states first resolve their own differences before they entertain relations with secretariats. This article provides an alternative perspective. It argues that individual or groups of states may collude with like-minded secretariats to achieve outcomes at the expense of other states. Working informally together is beneficial. States can benefit from the rational-legal, delegated, moral, and expert authority of secretariats. States and secretariats can also exchange resources. The article illustrates this perspective through two case studies: the NATO intervention in Libya in 2011 and the European Union's military operation in Chad in 2008. KEYWORDs: international secretariats, authority, principal-agent model.
\end{abstract}

THE AUTHORITY OF INTERNATIONAL SECRETARIATS HAS BECOME A MAJOR TOPIC in the discipline of international relations. ${ }^{1}$ From Jacques Delors at the helm of the European Commission to the technical expertise of officials in the World Health Organization (WHO), academics have shown how nonstate actors make a difference. When analyzing the authority of secretariats, they often dichotomize between states and secretariats: authority comes at the expense of the member states. This dichotomy is inherent in the theories used. Constructivists want to make a point about the independent contribution of nonstate actors. Principalagent scholars, by the nature of their model, distinguish between "principals" and "agents." They also tend to focus on the formal rules, in which the member states are normally treated as a collectivity.

In this article, I provide an alternative theoretical perspective. I argue that individual or groups of states team up with secretariats to achieve outcomes at the expense of other states. First, secretariats can be powerful allies for states due to their multiple sources of authority. ${ }^{2}$ Second, secretariats rarely have sufficient powers to ignore the interests of states. They normally need the support of a substantial number of states. Collusion between like-minded states and secretariats is a logical outcome. While collusion is informal, it includes a range of activities such as jointly confronting other states, precooking meetings, discussing strategies, and exchanging resources. 
Member states are often divided and this affects the authority of secretariats. Many scholars have focused on the "preference heterogeneity" between states and what this means for secretariats. ${ }^{3}$ The literature, however, almost exclusively focuses on the initial delegation phase and assumes a "collective principal." That is, member states first solve their differences before they delegate functions. After delegation, however, the policy dynamics are different. Authority will depend on the ability of secretariats to work with like-minded states. ${ }^{4}$ Collusion is particularly likely to take place under three conditions: states and secretariats have complementary resources, they share preferences, and the risk of a loss of reputation is small for the secretariat.

In the article, I provide empirical evidence from two case studies: the intervention of the North Atlantic Treaty Organization (NATO) in Libya in 2011 and the European Union (EU) military operation in Chad and the Central African Republic in 2008. While military intervention is an area where the role of secretariats is assumed to be limited, it is also domain where the capabilities of the member states differ significantly. We would thus expect key states to take the lead and work informally with the secretariat. This is precisely in line with the empirical evidence. Both secretariats pursued their own agendas in cooperation with key member states. They made use of their procedural advantages. Collusion took the form of private meetings and the exchange of staff.

I first discuss how conflict between states affects the authority of secretariats. I subsequently provide a new perspective by outlining how states and secretariats work together when making actual policy. I trace empirically NATO and EU planning, and point at key instances of collusion. These case studies should not be seen as a test of the theory, but rather as providing sufficient evidence of its plausibility as well as examples of how collusion works in practice.

\section{Divided States and the Authority of Secretariats}

In this article, I provide a new perspective on the authority of international secretariats. I start from the assumption that secretariats are not just the tools of states, but can be actors in their own right. ${ }^{5}$ As actors, they can decide to collude with member states to reach common objectives. Collusion in international organizations is defined as an informal agreement between two or more actors, normally defying the formal rules, with the purpose of coordinating behavior to reach commonly agreed objectives. ${ }^{6}$ I develop three conditions under which we are likely to see instances of collusion. First, states and secretariats have complementary resources. Second, they have similar preferences. Third, the risk of a loss of reputation for the secretariat is relatively low. Before outlining the argument, I discuss the current theoretical literature.

The theoretical literature on authority often pits secretariats against states. ${ }^{7}$ States collectively delegate tasks to secretariats. Secretariats pursue their own agendas. States sanction secretariats when they detect agency loss. 
The dichotomy is explicit in principal-agent models, but also implicit in many nonstate accounts of authority. It is useful to provide an overview of the existing propositions on divided states. The starting point is the conceptual distinction between a "collective principal" and "multiple principals." ${ }^{8} \mathrm{We}$ speak of a collective principal when the member states collectively interact with an agent. In the case of multiple principals, member states also unilaterally interact with the agent. Member states in the collective principal first have to go into conclave before they can reach out to the secretariat. In the case of multiple principals, there is no need for interstate agreement. Principals may actually be in competition with each other. Figure 1 shows the three types of principal-agent relations.

According to Mona Lynn, Daniel Nielson, and Michael Tierney, "Collective principals are overwhelmingly the most common type of principal that we observe when analyzing IOs [international organizations]." 9 This is formally correct yet ignores the anarchical state of international relations, incomplete contracting, and informal politics. ${ }^{10}$ States also vary in their ability to lobby and control secretariats. ${ }^{11}$ It is thus necessary to develop alternative propositions on how conflict between member states plays out. Many scholars are concerned with how conflict between states affects institutional design. States negotiate among themselves about whether to create an agent and delegate tasks. The perspective of a collective principal is appropriate. ${ }^{12}$ Following David Epstein and Sharyn O'Halloran, ${ }^{13}$ Darren Hawkins et al. note that "delegation typically requires states to resolve their policy conflicts before they can decide to grant conditional authority to an agent ... [ $\mathrm{t}]$ he greater the preference heterogeneity . . . the less likely they will be to delegate to an IO."14

\section{Figure 1 Single, Collective, and Multiple Principals}

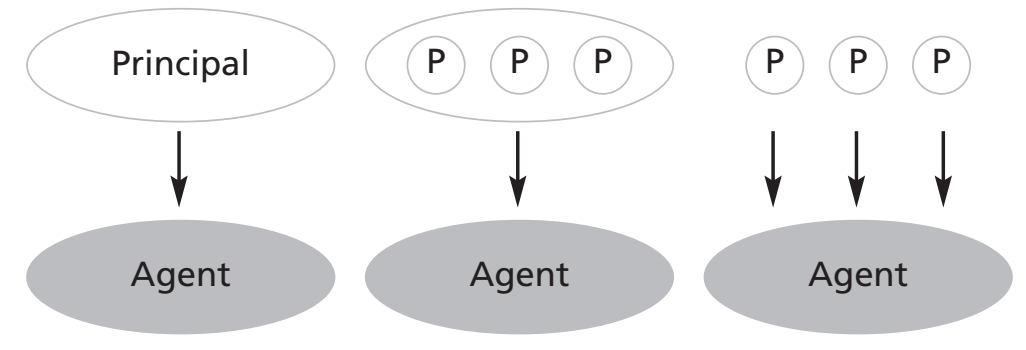

Sources: Based on Daniel Nielson and Michael Tierney, "Delegation to International Organizations: Agency Theory and World Bank Environmental Reform," International Organization 57, no. 2 (2003): 248; Mona Lynn, Daniel Nielson, and Michael Tierney, "A Problem of Principals: Common Agency and Social Lending at the Multilateral Development Banks," in Darren Hawkins, David Lake, Daniel Nielson, and Michael Tierney, eds., Delegation and Agency in International Organizations (Cambridge: Cambridge University Press, 2006), p. 45. 
Other scholars provide a different story. They point at the absence of hierarchy and the need for credible commitments. ${ }^{15}$ Precisely when the member states are divided, they need an agent to adjudicate.

In this article I address instead what happens after delegation, where the distinction between the collective principal and multiple principals becomes relevant. Scholars in the former tradition point at the decisionmaking rules. In some international organizations, where secretariats have formal powers such as the exclusive right of initiative (e.g., EU or International Monetary Fund [IMF]) or where it is easier for the member states to adopt than to amend a proposal, secretariats can exploit divisions among states ${ }^{16}$ Scholars furthermore note that a large zone of possible agreement allows secretariats to propose initiatives with a bias toward their own goals. ${ }^{17}$

The multiple principals perspective provides a different view. Individual states or groups of states will try to act through secretariats to achieve outcomes close to their individual preferences. ${ }^{18}$ Johannes Urpelainen has proposed a model in which states compete for control over the resources of secretariats. ${ }^{19}$ By lobbying secretariats, states try to affect secretariat preferences and redirect some secretariat authority toward their own interests. ${ }^{20}$ Scholars note that states value having their own nationals in key positions in secretariats. ${ }^{21}$ The idea of unilateral influence is attractive since it adds an informal dimension. Yet there is a tension. States will try to influence a secretariat only if it has significant authority. But authoritative secretariats are the most difficult to influence. Nitsan Chorev, for instance, shows how the WHO staff fend off pressures from the Global North and Global South. ${ }^{22}$ The unilateral influence agenda dismisses secretariat authority, but logically requires it.

In this article I build on these perspectives, but treat secretariats as actors in their own right rather than as instruments of the powerful member states. As actors, they can decide to collude with member states to reach common objectives. Rather than sitting opposite to the member states, secretariats sit among them when policy is made. Secretariats might be short on formal powers, but they make up for it through other forms of authority. ${ }^{23}$ Secretariats may not be the primary actors in international organizations, but they still can lend weight to likeminded member states. While collusion is almost always informal, it may involve precooked meetings and joint negotiations strategies as well as the exchange of resources. It is useful, in this respect, to define several scope conditions.

The first condition is that collusion between states and secretariats requires complementary resources. When states and secretariats combine those resources, they stand a better chance of achieving their preferred policy outcomes. Secretariats often possess rational-legal, delegated, moral, and expert authority, ${ }^{24}$ precisely because the member states do not. ${ }^{25}$ States have outsourced tasks resulting in a division of labor ${ }^{26}$ or they do not have authority to speak for the international community. ${ }^{27}$ Some secretariats thus possess key resources. This gives states incentives to work with secretariats. Similarly, secretariats are not able to achieve much without the support of member states. 
Complementary resources are therefore critically important. If secretariats are weak, there is no reason for states to work with them.

The second condition is that states and secretariats collude when they have similar preferences. While the literature on member state coalitions lists various reasons for cooperation, ${ }^{28}$ there is reason to treat this literature with caution. When states act through groups or coalitions, their rationale may be to reduce negotiation complexity (negotiations with too many actors is not practical) or to gather a voting majority. Collusion between states and secretariats serves neither purpose. Collusion is therefore more likely based on preference affinity: states and secretariats will work together only when they agree on an issue. Collusion is thus likely issue dependent.

The third condition is that collusion should not put the reputation of secretariats excessively at risk. Indeed, collusion between states and secretariats differs from the coordination behavior between states. Most secretariats have to be impartial as a result of their formal mandate. Collusion between states and secretariats thus cannot be as explicit as coordination between states. It is likely to be informal, tacit, and secretive. When a secretariat openly backs a member state, it might lose its (perceived) neutrality, its authority, and therefore its added value. This puts limits on collusion. Collusion therefore takes place when the benefits outweigh the risk of damage to the secretariat's reputation.

In addition to these three conditions, we need to consider when collusion takes place. There are opportunities throughout the policy process. Agendasetting scholars have suggested that conflict expansion-to enlarge the group of involved actors with supporters - is a strategy to put pressure on opposing actors. ${ }^{29}$ If the secretariat is on board, this might convince some other member states as well. Secretariats also often have procedural powers. During decisionmaking, the secretariat's authority often depends on its information advantage versus the opposing member states. Such an advantage allows it to construct policy alternatives and misrepresent the consequences of those alternatives. ${ }^{30}$ Rather than relying on its own resources, the secretariat can increase its information advantage by exchanging information with like-minded states. Finally, during implementation, secretariats often benefit from support and buy-in by the member states. States can also shield secretariats from ex post sanctions.

To sum up the argument: the member states are often divided on policy. To achieve their preferences, individual or groups of member states may team up with the secretariat. Secretariats also have incentives to work with likeminded states. This idea of collusion challenges the conventional wisdom in the theoretical literature that the authority of secretariats comes at the expense of the membership. It also challenges the dichotomy between states and secretariats. The authority of secretariats benefits some states and it hurts others. There are three conditions for collusion to occur. First, states and secretariats need to have complementary resources. Second, states and secretariats need to have preference affinity. Third, the benefits of collusion must outweigh the risks of reputation loss for the secretariat. 
To show the plausibility of the theory, and to give examples of how collusion may work in practice, in this article I provide insights from two case studies: the NATO operation in Libya in 2011 and the EU operation in Chad in 2008. The field of security is widely considered a least likely area for secretariat authority, as the member states are wary about sovereignty costs. The NATO international staff and the EU's Directorates on the Common Security and Defence Policy (CSDP) are nonetheless serious bureaus. ${ }^{31}$ While short on formal powers, they have considerable content and procedural expertise. This means that the first condition is met. In both cases, the member states disagreed on intervention. This makes it relatively easy to identify preference affinity, which is the second condition. Finally, the potential gains from collusion were significant and trumped the potential loss of reputation, which satisfies the third condition. In the case studies, I discuss these three conditions and identify instances of collusion in the different phases of the policy process.

\section{The NATO Operation in Libya}

At the end of 2010 protests broke out in what became known as the Arab Spring. Several protests escalated such as in Libya where security forces used live ammunition. By late February 2011, the government of Colonel Muammar Qaddafi deployed military force to retake the eastern city of Benghazi. The international community acted quickly. The UN Security Council adopted Resolution 1973 on 17 March authorizing military intervention. This resolution was given effect two days later, when an ad hoc coalition of France, the United Kingdom, and the United States started carrying out air strikes. On 31 March, military authority was transferred to NATO. Shortly after Qaddafi's death, NATO terminated its operation on 31 October 2011. This case study analyzes NATO planning during March 2011. It focuses on how NATO secretary general Anders Fogh Rasmussen and his officials in the international staff used their authority to the advantage of pro-interventionist allies.

It is first important to establish that the NATO secretary general and his officials are serious actors with complementary resources. NATO is often seen as an intergovernmental alliance where consensus rules and the United States acts as the primus inter pares. ${ }^{32}$ The authority of NATO officials is significant nonetheless. First, they are the permanent chairpersons of the North Atlantic Council (NAC) and its committees. This involves procedural powers, such as agenda-setting, but also a role as a broker. ${ }^{33}$ Second, the international staff act as a gatekeeper between the member states and the military command structure. Third, as a former prime minister, Rasmussen had some personal authority and networks, which most national ambassadors lacked. ${ }^{34} \mathrm{He}$ also acted as the spokesperson of the alliance.

Moving toward the second condition, the NATO intervention was an example of divided member states. The United States and the United Kingdom favored the transfer of authority from the ad hoc coalition to NATO. This 
would relieve the United States from a command burden. France, on the other hand, was hesitant to use NATO. It feared that NATO would constrain the operation and limit its own role. Germany had infamously abstained from Resolution 1973 and was not supportive of a NATO role. Turkey was against a NATO mission in the Arab neighborhood while Poland and many Central and Eastern European states did not want to commit troops. ${ }^{35}$

The position of the NATO secretary general and the international staff was therefore critical. While Rasmussen initially avoided the spotlight, he quickly became a supporter of NATO involvement. It was in his institutional interest. He saw it as a good opportunity to show the relevance of NATO beyond Afghanistan. There was thus preference affinity between some allies and the international staff. Yet Rasmussen and his officials did not sheepishly follow the pro-interventionist allies. They stressed that NATO had to bring added value to the operation ${ }^{36}$ and that NATO had to stay within the UN Security Council mandate. ${ }^{37}$ As such, their preferences were more restrictive than those of some allies. ${ }^{38}$ Despite the alignment, Rasmussen and his officials therefore pursued their own preferences.

To obtain an insight of how collusion was organized, it is important to analyze NATO planning. This provides a better understanding of the third condition - the trade-off between the benefits of collusion for the secretariat and the risks of choosing sides. While the allies debated the NATO transfer during the second half of March, a lot of informal planning had already been done with a strong informal involvement of the NATO agents. By late February, the NATO military authorities started "prudent planning." On 4-10 March, Rasmussen convened the NAC almost on a daily basis. On 10 March, NATO initiated formal planning. Indeed, military planning was carried out before the member states settled their own differences. NATO officials not only sat at the negotiation table; they also chaired the negotiations, pushed the planning, and kept the momentum going.

The first step was to get the situation in Libya on the agenda. France objected to discussing Libya. Yet when the situation deteriorated, Rasmussen used his procedural powers to convene an NAC emergency meeting on 25 February. ${ }^{39}$ Shortly afterward, the NAC instructed the Supreme Headquarters Allied Powers Europe (SHAPE) to start prudent planning. ${ }^{40}$ Led by four-star US admiral James Stavridis, this allowed SHAPE to write a nonpaper about the no-fly zone, which would become the cornerstone of the mission. ${ }^{41}$ NATO deployed AWACS (Airborne Warning and Control System) aircraft on 8 March to provide surveillance ${ }^{42}$ and increased its maritime presence. It also launched planning on humanitarian assistance and an arms embargo on 10 March. While largely sideshows, this gave the ambassadors something to talk about. The United States was the main driver. As one interviewee states, "The idea is to push the planning ... [t] he objective was to have NAC meetings and to start the planning." 43 Rasmussen facilitated this process by using his procedural powers. This is complementary authority, which can be used to support like-minded member states during agenda setting. 
The real bone of contention was the no-fly zone. Establishing a no-fly zone would require a serious military engagement. NATO first had to take out Libya's air defenses. ${ }^{44}$ Maintaining a no-fly zone would also be costly. Previous experience had shown that a no-fly zone in and of itself would not end the civil war. ${ }^{45}$ The no-fly zone was extensively debated. Prudent planning for a no-fly zone started at the end of February, but it long remained unclear whether there would be sufficient political will to launch the mission. The UN Security Council adopted Resolution 1973 on 17 March. Only on 15 March had US president Barack Obama come out in favor. ${ }^{46}$ Resolution 1973, however, not only imposed a no-fly zone, but also authorized "all necessary measures" to protect civilians. ${ }^{47}$ While the most controversial point, it was a last-minute addition in a response to the developing situation. As such, it received far less attention.

On 19 March, President Nicolas Sarkozy announced that he had unilaterally authorized air strikes. The United States and the United Kingdom joined the same day. These countries made up the core of the ad hoc coalition. Coalition operations were coordinated by the United States through United States Africa Command (AFRICOM) and the command ship USS Mount Whitney. Various NATO officers were included in the coalition. ${ }^{48}$ Rear Admiral Russ Harding came, for instance, from NATO. Stavridis was involved in the coalition, as he also directed US European Command supporting AFRICOM. Once NATO took over authority, many officials moved back. ${ }^{49}$ That staff was temporarily exchanged is evidence of the close cooperation among France, the United Kingdom, the United States, and NATO authorities.

Almost immediately after the launch of the coalition operations, it became clear that the ad hoc command structure was not workable. ${ }^{50}$ While the United States had previously acted as a framework nation for coalition operations, ${ }^{51}$ it noted, on day three, that it did not want to be responsible this time around. ${ }^{52}$ The United Kingdom also called for NATO to take over from the coalition. Prime Minister David Cameron stated that the coalition is "operating under U.S. command with the intention that this will transfer to NATO . . . [c]learly the mission would benefit from that and from using NATO's tried-and-tested machinery in command and control."53

Understanding that this could be a good opportunity for NATO, the secretary general and his staff played a role. As the go-between for the member states and the military command structure, they put tremendous pressure on SHAPE to get the planning done quickly. ${ }^{54}$ As a result, SHAPE "sent $80 \%$ " of the Operations Plan. ${ }^{55}$ SHAPE furthermore sent the Operation Plan rather late to put extra pressure on the member states ${ }^{56}$ A procedural trick by NATO officials was also the use of silence procedures with short deadlines. This put obstructive member states on the spot. ${ }^{57}$ The NATO secretariat in close cooperation with the US leadership at SHAPE thus used its authority to the advantage of pro-interventionist allies. 
Negotiations over NATO involvement reached a critical stage during the week of 21 March. It started off with Rasmussen insisting on the use of NATO and the French and German ambassadors walking out of the room. ${ }^{58}$ While this shows the limits of Rasmussen's authority and the risk of being perceived as biased, it also usefully put everyone under pressure. The next day, the ambassadors reconvened and managed to find agreement on the no-fly zone. They continued to disagree, however, on strike actions. Turkey insisted that all military operations would come under NATO. It would then have a say and the ability to restrict strike actions. France, meanwhile, wanted to keep NATO away from the strike actions. ${ }^{59}$ On 24 March, France finally gave in following US pressure. ${ }^{60}$ The transfer of authority from the coalition to NATO took place a week later.

When looking at the NATO intervention in Libya, there are several conclusions. First, it makes little sense to dichotomize between allies and the secretariat. NATO agents did not wait with their planning until the allies had reached an agreement. Indeed, they tried to affect the political decision. They did so against the wishes of some member states. Rasmussen became a supporter of a NATO mission. This was about institutional interests. He used his procedural power to convene meetings, speed up the planning, and put pressure on the NATO system and he pleaded for a political agreement. While there were limits to the authority of the NATO secretary general and his staff, this was significant nonetheless.

Second, the preferences of Rasmussen and his staff were aligned with those of the United States and the United Kingdom. The United States and the United Kingdom benefited from Rasmussen exerting his authority. Rasmussen was not just sitting at the table waiting for his instructions. He chaired the NAC and used his delegated and expert authority. Third, while it is difficult to trace informal meetings between member states and secretariats, it is worth pointing at the triangle of the US ambassador, NATO secretary general Rasmussen, and Stavridis at SHAPE. Stavridis notes that "my diplomatic 'wing man,' U.S. Ambassador to NATO Ivo Daalder, did the political side of this, and we talked a couple of times a week to keep in sync." ${ }^{1}$ The exchange of staff between NATO and the coalition is further evidence of collusion. The risk of being perceived as biased became a concern secondary to launching the mission.

\section{The EU Operation in Chad}

The EU military intervention in Chad and the Central African Republic resulted from a desire to do something about the situation in Darfur in neighboring Sudan. Since the beginning of the conflict in Darfur in 2003, about 250,000 refugees had left for eastern Chad. To improve the situation in the refugee camps, the UN suggested a multidimensional presence consisting of military, police, and humanitarian workers. The Chadian president, Idriss 
Déby, however, made clear that the UN military component would not be welcome. ${ }^{62}$ As a compromise, the EU sent instead a military mission of 3,700 troops for a period of one year. ${ }^{63}$ Afterward, the UN took over. President Déby could accept a French-led EU mission, as France also bilaterally guaranteed the stability of his regime.

This case study analyzes the EU planning process in 2007. It focuses on how EU officials used their procedural authority to the advantage of France. As with the case of NATO, and in line with the first condition, it is important to establish that the EU officials in the CSDP Directorates were serious actors with significant resources. Three sources of authority can be identified. First, while EU officials did not chair the meetings at the time, they had a considerable authority over the rotating presidency in agenda management. ${ }^{64}$ Second, the CSDP Directorates are in charge of drafting strategic planning documents for which they have considerable expertise. ${ }^{65}$ Third, the EU high representative at the time, Javier Solana, had personal authority and international networks. ${ }^{66}$ As such, EU officials are useful allies for member states.

With respect to the second condition, the EU intervention in Chad was another example of divided member states. France was a proponent. Darfur had featured prominently in the 2007 elections and was a priority for President Sarkozy and Foreign Minister Bernard Kouchner. ${ }^{67}$ Most other member states were skeptical. The United Kingdom noted its commitments elsewhere. Germany was wary of using force in Africa. It was generally felt "that however well intentioned the operation, in the end it would serve French interests the most." ${ }^{68}$ Solana and his officials had pro-interventionist preferences. ${ }^{69}$ They considered that EU security policy could be further developed. Their preferences were thus aligned with those of France.$^{70}$ For EU officials, however, it was important that the operation would be realistic. Dealing directly with Darfur was considered a nonstarter. They preferred an operation in Chad in support of the efforts of the UN. ${ }^{71}$ As such, French and EU preferences were not fully aligned.

Despite significant opposition, France in collusion with EU officials launched this operation. They worked together from the beginning, cooperation that was facilitated by the large number of French nationals in the EU planning services. France ended up carrying a large part of the burden of the eventual military mission, but the interaction with EU officials provides an instance of the theory.

For France, it was beneficial to work closely with the EU officials not just for their procedural expertise. Proposals coming out of Brussels were regarded as less biased than ideas from Paris. The blessing by the EU officials was important for other states, such as Ireland, which provided the operations commander.

To analyze the trade-offs between the benefits from collusion and the risk of being perceived as biased, it is necessary to trace the planning process. The EU operation came on the agenda after the French elections. Kouchner directly convened a meeting and sent a telegram to the EU partners requesting 
an options paper. ${ }^{72}$ Without the knowledge of the other member states, EU officials were also invited to the French military headquarters in Paris. ${ }^{73}$ If France was to do anything, it would have a natural ally in the EU officials. ${ }^{74}$ The EU Directorate for Defence Issues was furthermore, at the time, a French fiefdom led by Claude-France Arnould. Following this meeting, Kouchner met with Déby on 10 June. UN sources report that Déby agreed "to the deployment of an international military presence in eastern Chad composed of French and other European Union forces."75 They also state that "a United Nations military presence was not favoured by the Chadian Government, although it could eventually be discussed as a second phase of a United Nations deployment."76

The process started moving in the EU with an options paper on 13 July 2007. For the EU officials, it was an opportunity to "[kill] the stupid ideas." "77 All ideas for EU action in Darfur lacked support from the local government and the humanitarian community. ${ }^{78}$ The only thing remaining for the EU was to "close the two backdoors in order to avoid spillover in Chad and the Central African Republic."79 The options paper marked the start of the planning process that would eventually lead to political agreement on 15 October. It is tracing the process, as it shows how different tricks were employed. Furthermore, a discussion of the planning process shows that political agreement came after the planning.

At the end of August, EU officials went on a fact-finding mission to the region. ${ }^{80}$ Based on their findings, they presented a Crisis Management Concept. It was adopted on 12 September. The concept described the overall parameters of the EU's possible involvement. The next step in the process was to get UN Security Council authorization. There were two competing agendas. For the EU, it had to be clear that the UN would take over after one year. The Chadian government, however, remained reluctant to host UN peacekeepers. Getting clarity about the handover would lead to delays. France pushed for a compromise: to postpone the decision on the handover until the EU mid-mandate review. While this created ambiguity, it allowed France and the EU officials to move ahead with planning. ${ }^{81}$

The member states then discussed the Military Strategic Options. EU officials presented the member states with four options. ${ }^{82}$ These options were drafted in a way that only option three was realistic. It would involve the deployment of four battalions before the start of the rainy season. The other options were either too light, geographically unappealing, or required deployment during the rainy season. After the member states chose indeed option three, planning was only a matter of legalizing all the decisions in a political agreement. It soon turned out, however, that the EU officials had underestimated the common costs. The common costs, borne by all member states, increased in the weeks after the adoption of the options. While EU officials had a formal excuse - the budgets for the options were preliminary - it is difficult to escape the impression that this was an instance of an exploited information advantage.

While agreement was reached, it became clear that few member states actually wanted to contribute. Since Germany and the United Kingdom were not 
in favor of the operation, France would be the only big state providing troops. This meant that France would potentially have to pay for almost the whole operation. To reduce its burden, France looked for contributions from the other states. This proved difficult. One reason why the member states were reluctant was the perception of French bias. The EU could make a meaningful contribution, but it would have to be an impartial actor in Chadian politics. Yet due to French bilateral support to the local government, few member states saw how this was going to happen. Various member states were, however, enthusiastic about the EU mission being part of a broader multidimensional presence supporting UN activities. Furthermore, the concept of a bridging operation was appealing. ${ }^{83}$

France started to lobby intensively for military contributions at the highest political level. It convinced Ireland to take the operational command and it also solicited a sizable contribution from Poland. Only after both countries made these contributions could the member states move forward. A shortfall, however, remained in terms of military enablers. The Irish commander noted that "it was not a luxury plan." 84

France took a leadership role in the EU mission, but it worked closely together with the EU officials. Rather than first seeking an agreement with the other member states, as the collective principal model suggests, France invited EU officials directly to its military planning headquarters. During the summer, France and the EU officials worked closely on the initial planning documents. Such cooperation was facilitated by the presence of French nationals in the EU planning services. As with the case of the NATO intervention, it is difficult to trace the precise information flows between France and these EU officials. Yet it is clear that planning documents were discussed between France and the EU officials before they were made available to the other member states.

Finally, it is worth saying something about the motives for collusion. France wanted an EU mission. Working together with the EU officials was a clear step to signal its intentions to the rest of the membership. It also knew it would have a strong ally in the EU officials in terms of the use of procedures. Making use of the authority of the EU officials was thus beneficial for France. For the EU officials, this also was a good opportunity to launch a new EU military operation. As they were building up EU security policy, they had an interest in the mission. The EU officials went out of their way to facilitate the French agenda.

\section{Conclusion}

Like-minded states often work together in international organizations. Likeminded states and secretariats do the same. For individual or groups of states to achieve anything, they often require the support of secretariats. As the masters of the procedures and informal veto players, secretariats are useful allies. Secretariats themselves hardly ever possess the authority to pursue policy on their own or, let alone, against the wishes of the major states. They need backing as 
well. As the term suggests, collusion in international organizations between states and secretariats is often informal. Secretariats are formally impartial agents and cannot be seen as siding with part of the membership. If they are perceived as biased, they will lose some of their authority. And yet collusion can be extensive, rather explicit, and involve the exchange of resources.

While this argument seems straightforward, the theoretical literature has hardly paid attention to the strategic interaction between states and secretariats. Much of the constructivist literature focuses on the authority of secretariats beyond states. Principal-agent models are concerned with conflict between principals and agents. They consider agency loss to be the difference between what the member states collectively decide and the policy implemented by the secretariat. This ignores the possibility that individual states may well benefit from secretariat authority. The informal governance literature addresses unilateral control, but reduces the authority of secretariats to a continuation of state power by other means.

In this article, I have provided empirical insights from two case studies. A generalization of these findings should be treated with caution, particularly when it concerns the wider and rather varied population of international organizations. A generalization would require additional empirical analysis. Yet it is worth pointing out several similarities in the two case studies. In both cases, it is evident that substantial military planning took place long before the member states reached an agreement. This puts the conventional collective principal perspective upside-down. The member states did not go into conclave to reach agreement first. Instead, the secretariats worked with likeminded states to get the planning ready, putting opposing states in front of a fait accompli. For states to block political agreement late in the game required them to challenge strong states such as the United States and France. The early involvement of secretariats was therefore significant.

Also interesting is the considerable interaction between the states and secretariats through the exchange of personnel. While SHAPE constitutes the source of NATO's military expertise, it is US led. One can make a similar observation for the EU mission. The strong French presence in the EU planning directorate made informal relations easier. Mareike Kleine has written about the national fiefdoms in international organizations. ${ }^{85}$ While she is certainly right that this presents a case of unilateral control, it is also important to conclude that fiefdoms facilitate collusion between states and secretariats. Furthermore, while US and French leadership in NATO and EU security is clearly significant, there tend to be fiefdoms, secondments, and political appointees across international secretariats more broadly.

There are also limits to using the authority of secretariats. In both cases, opposing member states could be pressured into accepting the launch of a military operation. They could not be pressured into making actual military contributions. This was naturally a source of frustration for the United States and France, but at an analytical level it points to the limits of the authority of sec- 
retariats. Furthermore, secretariats need to permanently consider their reputation, which creates an obstacle for them to collude with states. This dilemma was captured in the third condition: the gains from collusion need to be significant for the secretariat to risk its reputation.

\section{Notes}

Hylke Dijkstra is assistant professor (with tenure) at the Department of Political Science, Maastricht University, the Netherlands. He has published extensively on policymaking in the EU, NATO, and the UN. He is the author of International Organizations and Military Affairs (2016) and Policy-making in EU Security and Defense (2013). These books include chapters on the NATO intervention in Libya and the EU intervention in Chad, on which this article builds. The research leading to these results has received funding from the People Programme (Marie Curie Actions) of the European Union's Seventh Framework Programme (FP7/2007-2013) under Research Executive Agency Grant Agreement no. 298081.

1. Authority is broader than formal discretion. Oran Young, "Political Leadership and Regime Formation: On the Development of Institutions in International Society," International Organization 45, no. 3 (1991): 281-308; Bob Reinalda and Bertjan Verbeek, eds., Autonomous Policy Making by International Organizations (London: Routledge, 1998); Michael Barnett and Martha Finnemore, "The Politics, Power, and Pathologies of International Organizations," International Organization 53, no. 4 (1999): 699-732; Michael Barnett and Martha Finnemore, Rules for the World: International Organizations in Global Politics (Ithaca: Cornell University Press, 2004); Darren Hawkins, David Lake, Daniel Nielson, and Michael Tierney, "Delegation Under Anarchy: States, International Organizations and Principal Agent Theory," in Darren Hawkins, David Lake, Daniel Nielson, and Michael Tierney, eds., Delegation and Agency in International Organizations (Cambridge: Cambridge University Press, 2006), pp. 3-38; Frank Biermann and Bernd Siebenhüner, eds., Managers of Global Change: The Influence of International Environmental Bureaucracies (Cambridge: MIT Press, 2009); Nitsan Chorev, The World Health Organization Between North and South (Ithaca: Cornell University Press, 2012); Tana Johnson, Organizational Progeny: Why Governments Are Losing Control over the Proliferating Structures of Global Governance (Oxford: Oxford University Press, 2014); Liesbet Hooghe and Gary Marks, "Delegation and Pooling in International Organizations," Review of International Organizations 10, no. 3 (2015): 305-328; Steffen Eckhard and Jörn Ege, "International Bureaucracies and Their Influence on Policy-making: A Review of Empirical Evidence," Journal of European Public Policy 23, no. 7 (2016): 960-978.

2. Barnett and Finnemore, Rules for the World, pp. 20-29.

3. Hawkins et al., "Delegation Under Anarchy," pp. 20-21; Daniel Nielson and Michael Tierney, "Delegation to International Organizations: Agency Theory and World Bank Environmental Reform," International Organization 57, no. 2 (2003): 247-249; Jessica Green and Jeff Colgan, "Protecting Sovereignty, Protecting the Planet: State Delegation to International Organizations and Private Actors in Environmental Politics," Governance 26, no. 3 (2013): 477-478; Susan Allen and Amy Yuen, "The Politics of Peacekeeping: UN Security Council Oversight Across Peacekeeping Missions," International Studies Quarterly 58, no. 3 (2014): 623-625.

4. Kenneth Abbott, Philipp Genschel, Duncan Snidal, and Bernard Zangl analyze how international organizations strategically work through intermediaries such as NGOs. While this is a major advancement, the purpose of orchestration is (1) to manage states; or (2) to bypass states. Kenneth Abbott, Philipp Genschel, Duncan Snidal, and 
Bernard Zangl, eds., International Organizations as Orchestrators (Cambridge: Cambridge University Press, 2015), p. 11. This perspective thus dichotomizes as well between states and secretariats.

5. Cf. Barnett and Finnemore, Rules for the World.

6. Cf. Ole Elgström, Bo Bjurulf, Jonas Johansson, and Anders Sannerstedt, "Coalitions in European Union Negotiations," Scandinavian Political Studies 24, no. 2 (2001): 113. For a useful discussion of why informality defies formal rules, see Mareike Kleine, "Informal Governance in the European Union," Journal of European Public Policy 21, no. 2 (2014): 306-307.

7. There is a rich empirical literature on the authority of secretariats and there are plenty of anecdotes about how secretariat officials work together with member states' diplomats. Classics include Brian Urquhart, Hammarskjold (New York: Norton, 1972); James Traub, The Best Intentions: Kofi Annan and the UN in the Era of American World Power (London: Bloomsbury, 2006). For an overview see Silke Weinlich, The UN Secretariat's Influence on the Evolution of Peacekeeping (London: Palgrave Macmillan, 2014), pp. 38-55. In this article, however, I challenge the theoretical literature, which tends to dichotomize between states and secretariats.

8. Nielson and Tierney, "Delegation to International Organizations"; Mona Lynn, Daniel Nielson, and Michael Tierney, "A Problem of Principals: Common Agency and Social Lending at the Multilateral Development Banks," in Darren Hawkins, David Lake, Daniel Nielson, and Michael Tierney, eds., Delegation and Agency in International Organizations (Cambridge: Cambridge University Press, 2006), pp. 41-76.

9. Lynn, Nielson, and Tierney, "A Problem of Principals," pp. 44-45.

10. Johannes Urpelainen, "Unilateral Influence on International Bureaucrats: An International Delegation Problem," Journal of Conflict Resolution 56, no. 4 (2012): 707.

11. Randall Stone, Controlling Institutions: International Organizations and the Global Economy (Cambridge: Cambridge University Press, 2011); Diana Panke, "Lobbying Institutional Key Players: How States Seek to Influence the European Commission, the Council Presidency and the European Parliament," Journal of Common Market Studies 50, no. 1 (2012): 134-143; Hylke Dijkstra, "Shadow Bureaucracies and the Unilateral Control of International Secretariats: Insights from UN Peacekeeping," Review of International Organizations 10, no. 1 (2015): 29.

12. Tana Johnson challenges the distinction between delegation and postdelegation by arguing that secretariats also regularly sit around the table when delegation decisions are made. Johnson, Organizational Progeny.

13. David Epstein and Sharyn O'Halloran, "Divided Government and the Design of Administrative Procedures: A Formal Model and Empirical Test," Journal of Politics 58, no. 2 (1996): 374.

14. Hawkins et al., "Delegation Under Anarchy," pp. 20-21.

15. Barbara Koremenos, Charles Lipson, and Duncan Snidal, "The Rational Design of International Institutions," International Organization 55, no. 4 (2001): 787-791; Green and Colgan, "Protecting Sovereignty, Protecting the Planet," pp. 477-478; Hooghe and Marks, "Delegation and Pooling in International Organizations," p. 317.

16. Suzanne Schmidt, "Only an Agenda Setter? The European Commission's Power over the Council of Ministers," European Union Politics 1, no. 1 (2000): 37-61; Mark Pollack, The Engines of European Integration: Delegation, Agency, and Agenda Setting in the EU (Oxford: Oxford University Press, 2003), pp. 47-49; Lisa Martin, "Distribution, Information, and Delegation to International Organizations: The Case of IMF Conditionality," in Darren Hawkins, David Lake, Daniel Nielson, and Michael Tierney, eds., Delegation and Agency in International Organizations (Cambridge: Cambridge University Press, 2006), pp. 140-164, at 143. 
17. Martin, "Distribution, Information, and Delegation to International Organizations," pp. 143-145; Christina Schneider and Jennifer Tobin, "Interest Coalitions and Multilateral Aid Allocation in the European Union," International Studies Quarterly 57, no. 1 (2013): 105-106.

18. Kenneth Abbott and Duncan Snidal, "Why States Act Through Formal International Organizations," Journal of Conflict Resolution 42, no. 1 (1998): 3-32; Michael Manulak, "Leading by Design: Informal Influence and International Secretariats," Review of International Organizations (forthcoming).

19. Urpelainen, "Unilateral Influence on International Bureaucrats."

20. See, for example, Panke, "Lobbying Institutional Key Players."

21. Mareike Kleine, "Trading Control: National Fiefdoms in International Organizations," International Theory 5, no. 3 (2013): 321-346; Michal Parizek, "Control, Soft Information, and the Politics of International Organizations Staffing," Review of International Organizations (forthcoming).

22. Chorev, The World Health Organization Between North and South.

23. Barnett and Finnemore, Rules for the World, pp. 20-29.

24. Ibid.

25. For Johnson, secretariats are powerful when they have distinct forms of authority from the member states. Johnson, Organizational Progeny. See also Biermann and Siebenhüner, Managers of Global Change.

26. Jonas Tallberg, "Delegation to Supranational Institutions: Why, How, and with What Consequences?" West European Politics 25, no. 1 (2002): 25; Hawkins et al., "Delegation Under Anarchy," pp. 13-15.

27. Barnett and Finnemore, Rules for the World, p. 23.

28. See, for example, Arend Lijphart, "The Analysis of Bloc Voting in the General Assembly: A Critique and a Proposal," American Political Science Review 57, no. 4 (1963): 902-917; Erik Voeten, "Clashes in the Assembly," International Organization 54, no. 2 (2000): 185-215; Elgström et al., "Coalitions in European Union Negotiations."

29. Elmer Schattschneider, The Semisovereign People: A Realist's View of Democracy in America (Wadsworth: Cengage Learning, 1960), chap. 1; Roger Cobb, JennieKeith Ross, and Marc Ross, "Agenda Building as a Comparative Political Process," American Political Science Review 70, no. 1 (1976): 126-138.

30. Jonathan Bendor, Serge Taylor, and Roland Van Gaalen, "Bureaucratic Expertise Versus Legislative Authority: A Model of Deception and Monitoring in Budgeting," American Political Science Review 79, no. 4 (1985): 1042; Hawkins et al., "Delegation Under Anarchy," p. 25; Martin, "Distribution, Information, and Delegation to International Organizations," pp. 145-147.

31. The CSDP Directorates are part of the European External Action Service. At the time of this case study, they were in the Council of Ministers secretariat.

32. Exceptions include Sebastian Mayer, ed., NATO's Post-Cold War Politics: The Changing Provision of Security (Basingstoke: Palgrave Macmillan, 2014); Celeste Wallander, "Institutional Assets and Adaptability: NATO After the Cold War," International Organization 54, no. 4 (2000): 705-735; Hans Mouritzen, The International Civil Service: A Study of Bureaucracy: International Organizations (Aldershot: Dartmouth, 1990).

33. Jonas Tallberg, "The Power of the Chair: Formal Leadership in International Cooperation," International Studies Quarterly 54, no. 1 (2010): 241-265.

34. Ryan Hendrickson, "The Changing Role of NATO's Secretary General," in Sebastian Mayer, ed., NATO's Post-Cold War Politics: The Changing Provision of Security (Basingstoke: Palgrave Macmillan, 2014), pp. 124-139.

35. Interview no. 4, NATO diplomat, Brussels, 19 July 2013; interview no. 6, NATO International Staff, Brussels, 26 September 2013. All interviews were done on 
the basis of anonymity. Rebecca Adler-Nissen and Vincent Pouliot, "Power in Practice: Negotiating the International Intervention in Libya," European Journal of International Relations 20, no. 4 (2014): 889-911.

36. Interview no. 1, NATO International Staff, Brussels, 12 September 2013.

37. Interview no. 2, Strike Force NATO, phone, 22 July 2013.

38. Barack Obama, David Cameron, and Nicolas Sarkozy, "Libya's Pathway to Peace," New York Times, 14 April 2011.

39. NATO, Operation UNIFIED PROTECTOR Final Mission Stats, 2 November 2011, www.nato.int/nato_static/assets/pdf/pdf_2011_11/20111108_111107-factsheet _up_factsfigures_en.pdf.

40. Hillary Clinton, "Interview with Michele Kelemen of National Public Radio," US Department of State, Office of the Spokesman, 28 February 2011, www.state.gov /secretary/20092013clinton/rm/2011/02/157455.htm; James Stavridis, The Accidental Admiral: A Sailor Takes Command at NATO (Annapolis: Naval Institute Press, 2014), p. 53.

41. Clinton, "Interview with Michele Kelemen of National Public Radio"; John Broder, "U.S. and Allies Consider Libya No-fly Zone," New York Times, 27 February 2011; interviews no. 3, NATO International Staff, Brussels, 9 July 2013; no. 4; and no. 8, NATO International Military Staff, Brussels, 26 July 2013.

42. NATO, NATO and Libya, 28 March 2011, www.nato.int/cps/en/natolive/topics -71652.htm.

43. Interview no. 6.

44. David Sanger and Thom Shanker, "Gates Warns of the Risks of Imposing a Noflight Zone over Libya," New York Times, 3 March 2011.

45. Alexander Bernard, "Lessons from Iraq and Bosnia on the Theory and Practice of No-fly Zones," Journal of Strategic Studies 27, no. 3 (2004): 454-478; Jeremiah Gertler, Christopher Blanchard, Stephen Daggett, Catherine Dale, Jennifer Elsea, and Richard Grimmett, No-fly Zones: Strategic, Operational, and Legal Considerations for Congress (Washington, DC: Congressional Research Service, 2011).

46. Steven Erlanger, "G-8 Ministers Fail to Agree on Libya No-flight Zone," New York Times, 15 March 2011; Bruce Jones, "Libya and the Responsibilities of Power," Survival 53, no. 3 (2011): 53.

47. UN Security Council Resolution 1973, paragraph 4.

48. Interview no. 2.

49. Ibid. As James Stavridis writes, "Command of the operations shifted from Carter Ham [at AFRICOM] and me as the supporting European commander to the supreme allied commander in Europe - who was also me, of course." Stavridis, The Accidental Admiral, p. 55.

50. Interviews no. 3, no. 4, no. 6; interview no. 5, NATO International Staff, Brussels, 16 September 2013.

51. Sarah Kreps, Coalitions of Convenience: United States Military Interventions After the Cold War (Oxford: Oxford University Press, 2011).

52. "Libya: US to Reduce Role in Military Campaign," BBC, 21 March 2011, www.bbc.co.uk/news/world-africa-12813757; Ewen MacAskill and Nick Hopkins, "Libyan Operation Hampered by Confusion and Dispute," The Guardian, 21 March 2011; interview no. 7, NATO International Military Staff, location withheld, 11 September 2013.

53. Prime Minister David Cameron, as quoted in Steven Erlanger, "Confusion over Who Leads Libya Strikes, and for How Long," New York Times, 21 March 2011.

54. Interviews no. 7 and no. 8.

55. Interview no. 8.

56. Interview no. 7. 
57. Ibid.

58. Kim Willsher, "Sarkozy Opposes NATO Taking Control of Libya Operation," The Guardian, 22 March 2011.

59. Ian Taynor and Nicholas Watt, "Libya: NATO to Control No-fly Zone After France Gives Way to Turkey," The Guardian, 25 March 2011.

60. Interviews no. 4 and no. 6.

61. Stavridis, The Accidental Admiral, p. 58; interview no. 7.

62. United Nations, "Report of the Secretary-General on Chad and the Central African Republic," UN Doc. S/2007/488 (10 August 2007), pars. 5-6; Patrick Berg, "EUFOR Tchad/RCA: The EU Serving French Interests," in Muriel Asseburg and Ronja Kempin, eds., The EU as a Strategic Actor in the Realm of Security and Defence (Berlin: Stiftung Wissenschaft und Politik, 2009), pp. 57-69.

63. The EU also sent a small contingent to the Central African Republic.

64. Christiansen Thomas and Sophie Vanhoonacker, "At a Critical Juncture? Change and Continuity in the Institutional Development of the Council Secretariat," West European Politics 31, no. 4 (2008): 751-770.

65. Hylke Dijkstra, Policy-making in EU Security and Defense: An Institutional Perspective (Basingstoke: Palgrave Macmillan, 2013).

66. Xymena Kurowska, “Solana Milieu': Framing Security Policy,” Perspectives on European Politics and Society 10, no. 4 (2009): 523-540; Gisela Müller-BrandeckBocquet and Carolin Rüger, eds., The High Representative for the EU Foreign and Security Policy: Review and Prospects (Baden-Baden: Nomos, 2011).

67. "Darfur to Top Agenda for French FM Kouchner," Agence France-Presse, 18 May 2007.

68. Alexander Mattelaer, "The Strategic Planning of EU Military Operations - The Case of EUFOR Tchad/RCA," IES Working Papers No. 5 (Brussels: Institute for European Studies, 2008), p. 16.

69. Dijkstra, Policy-making in EU Security and Defense, pp. 34-36.

70. Interview no. 11, European Commission, Brussels, 11 January 2010.

71. Interview no. 9, Council Secretariat, DG E VIII, Brussels, 3 December 2009.

72. Ibid.; Mattelaer, "The Strategic Planning of EU Military Operations," p. 14.

73. Interview no. 11.

74. Ibid.

75. United Nations, "Report of the Secretary-General on Chad and the Central African Republic," par. 25.

76. Ibid., par. 23.

77. Mattelaer, "The Strategic Planning of EU Military Operations," p. 14; interview no. 9 .

78. Berg, "EUFOR Tchad/RCA," pp. 59-60.

79. Interview no. 13, EU general, Brussels, 29 October 2009.

80. Interview no. 15, UN official, phone, 1 February 2010.

81. Interview no. 9.

82. Mattelaer, "The Strategic Planning of EU Military Operations," p. 16; interview no. 14, EU diplomat, Brussels, 16 November 2009.

83. Interview no. 14; interview no. 16, EU diplomat, Brussels, 29 October 2009; interview no. 17, EU diplomat, Brussels, 12 January 2010.

84. Interview no. 10, Council Secretariat, DG E VIII, Brussels, 19 January 2010.

85. Kleine, "Trading Control." 
In addition to the members of our editorial board, the following people generously shared their time and expertise in reviewing for

Global Governance. We are deeply indebted to these reviewers:

Pami Aalto
Alan Alexandroff
Emmanuel Kwesi Aning
Lorand Bartels
Adrian Bazbauers
Mark Beeson
Curtis Bell
Alex Bellamy
Mark T. Berger
Ljiljana Biukovic
Jane Boulden
Andrew Boutton
Garrett Brown
Michael Brzoska
Benedicte Bull
Sean Burges
Mely Caballero-Anthony
Charli Carpenter
Jean-Loup Chappelet
Simon Chesterman
Tom Chodor
Liam Clegg
Andrea Collins
Andrew Cooper
John Dryzek
William Durch
Martin S. Edwards
Edwin Egede
Par Engstrom
Gonzalo Escribano
Lorenza Fontana
Elisabeth Jay Friedman
Kizzy Gandy
Azmat Gani
Borja Garcia
Nathan Grills

\begin{tabular}{c} 
William Harris \\
Anthony Hazard \\
Richard Higgott \\
Neil Hirst \\
Rhoda Howard-Hassmann \\
Jutta Joachim \\
Arie Kacowicz \\
Adam Kamradt-Scott \\
Scott Kastner \\
Inge Kaul \\
Kai Michael Kenkel \\
Ann Kent \\
Inkyoung Kim \\
Daniel Kono \\
Khalid Koser \\
Melissa Labonte \\
Andrew Lang \\
Deborah Larson \\
Edward Laurance \\
Pak Lee \\
SungYong Lee \\
Ralf Leiteritz \\
George Lopez \\
Andres Malamud \\
Kevin Mazur \\
Padraig McAuliffe \\
Federico Merke \\
Timothy Meyer \\
Jason Miklian \\
Alistair Millar \\
Jeannette Money \\
Chungin Moon \\
Paul Nelson \\
Helen Nesadurai \\
Martin Niemetz \\
Leslie Ochreiter \\
\hline
\end{tabular}

John Odell

Henk Overbeek

Susan Park

Margaret Pearson

Charles Pentland

Nicolas Perrone

Tony Porter

Karsten Ronit

Steven Roper

Nicholas Rose

Michael Sander

Wayne Sandholtz

Johan Schaffer

Stefan Schirm

Albrecht Schnabel

Hakan Seckinelgin

Scott Shackelford

Dustin Sharp

Timothy Shaw

Elizabeth Sidiropoulos

Theresa Squatrito

Adam Stepien

Olav Schram Stokke

Oliver Stuenkel

Tim Summers

Mark Thurber

Robert Wade

Jeni Whalan

Taehee Whang

Andrew Wolman

Frances Woolley

Oran Young

Alasdair Young

Gentian Zyberi 